\title{
PYOGENIC LIVER ABSCESS: DIAGNOSTIC AND THERAPEUTIC MANAGEMENT
}

\author{
Abscesso hepático piogênico: manejo dos recursos diagnósticos e terapêuticos
}

Otto Mauro dos SANTOS-ROSA², Henrique Simonsen LUNARDELLI², Marcelo Augusto Fontenelle RIBEIRO-JUNIOR ${ }^{1,2}$

From the 'Departamento de Cirurgia Geral, Hospital Geral do Grajaú, and 2Universidade Santo Amaro ('Department of General Surgery, General Hospital of Grajaú, and 'Santo Amaro University), São Paulo, SP, Brazil.

HEADINGS - Pyogenic liver abscess. Drainage. Ultrasonography, interventional. Hypoalbuminemia.
ABSTRACT - Background: The pyogenic liver abscess has an incidence of 1.1/1,000 habitants. Mortality can reach $100 \%$. The use of less invasive procedures diminish morbidity and hospital stay. Aim: Identify risk factors in patients who underwent percutaneous drainage guided by ultrasound as treatment. Method: Were analyzed 10 patients submitted to the method. Epidemiological characteristics, laboratory markers and imaging exams (ultrasound and CT) were evaluated. Results: The majority of the patients were men with mean age of 50 years old. Liver disease, alcoholism and biliary tract disease were the most common prodromes. Abdominal pain (90\%), fever $(70 \%)$ and jaundice $(40 \%)$ were the most common clinical manifestations. Mortality of $20 \%$ was observed in this series. Hypoalbuminemia and days of hospitalization had a statistically significant positive association with death. Conclusion: The pyogenic liver abscess has subacute evolution which makes the diagnosis difficult. Image exams have high sensitivity in diagnosis, particularly computed tomography. Percutaneous drainage associated with antibiotic therapy is safe and effective therapeutic resource.

\section{Correspondence:}

Otto Mauro dos Santos Rosa

E-mail: ottomsrosa@yahoo.com.br

Financial source: none

Conflicts of interest: none

Received for publication: 02/03/2016 Accepted for publication: 02/06/2016

DESCRITORES - Abscesso hepático piogênico. Drenagem. Ultrassonografia de intervenção. Hipoalbuminemia.
RESUMO - Racional: O abscesso hepático piogênico tem incidência de 1,1 por 1.000 habitantes com mortalidade podendo chegar a 100\%. O uso de recursos menos invasivos diminuem morbimortalidade e tempo de internação hospitalar. Objetivo: Identificar fatores de risco no abscesso hepático piogênico tratado por drenagem percutânea guiada por ultrassom. Método: Total de 10 pacientes foram submetidos ao procedimento. Foram avaliadas características epidemiológicas, marcadores laboratoriais exames de imagem (ultrassom e tomografia). Resultados: Na amostra houve predominância do sexo masculino, com média de idade de 50 anos. Hepatopatia, etilismo e doença da via biliar foram os pródromos mais frequentes. Dor abdominal (90\%), febre (70\%) e icterícia (40\%) foram manifestações clínicas mais comuns. Houve mortalidade de $20 \%$ nesta série. Hipoalbuminemia e dias de internação hospitalar tiveram associação positiva com óbito estatisticamente significante. Conclusão: O abscesso hepático piogênico tem evolução subaguda o que dificulta o diagnóstico. Exames de imagem têm sensibilidade alta na propedêutica diagnóstica, notadamente a tomografia computadorizada. A drenagem percutânea, associada à antibioticoterapia, mostrou ser recurso terapêutico seguro e eficaz.

\section{INTRODUCTION}

yogenic hepatic abscess is caused by the development of intra-hepatic pus collection, secondary to a local inflammatory reaction by bacteria infection in the hepatic parenchyma ${ }^{9,16}$.

It has an incidence varying from 1,1-2,3 for each 100.000 habitants $^{3}$. The main symptoms are abdominal pain - mainly in the right hypochondrium - fever and hepatomegaly. It has a subacute evolution with symptoms varying between 3-120 days ${ }^{8}$.

The etiology can vary according to region. In Central Europe prevails biliary causes, followed by cryptogenic abscess by Staphylococcus aureus, Streptococcus and E. coli. In Southeast Asia, the most prevalent microorganism is Klebsiella pneumoniae. Such differences in the microbiological spectrum have implications in risk and course factors of the disease ${ }^{3}$. Pang et al. ${ }^{14}$ found a higher proportion of cryptogenic causes, followed by biliary and portal (appendicitis, diverticulitis). Also, verified association between microbiology and etiology. E. coli is associated with biliary diseases; Klebsiela with cryptogenic and Streptococcus milleri with portal causes.

It is a very harmful disease, always fatal without treatment. Mortality can vary between $5,6-80 \%^{10,13}$. A series published in 1938 , showed mortality of $60-80 \%^{9}$. An expressive downfall on the mortality rate, to $13-18 \%$, was possible because of the effective use of antibiotics after $1980^{11}$. Another decrease was seen in studies with the use of CT scan and ultrasound. The mortality in studies during and after 1990, remained between $4-10 \%{ }^{15}$. The development of interventional radiology, with percutaneous drainage guided by image and minimal invasive surgery, on recent decades, are contributing for the increase of patient's survival ${ }^{11}$.

The treatment to be instituted must consider the cause, the service's experience and the access to diagnostic means and treatment. Antibiotics, interventional radiology, 
and surgical therapy can be used, combined or as a single therapy. However, the combination of interventional radiology (aspiration or drainage) with antibiotics has shown better results in hospitalization, morbidity, mortality and complications ${ }^{5,13}$.

The aim of this study was to identify risk factors of pyogenic liver abscess treated by percutaneous drainage guided by ultrasound.

\section{METHOD}

This is a prospective study in which all patients included were treated in Hospital Geral do Grajaú, São Paulo, SP, Brazil for pyogenic hepatic abscess. Ten patients were included in the period between April and September 2015.

The diagnosis of pyogenic hepaticabscess was confirmed based on clinical characteristics, laboratorial and image exams (ultrasound and tomography). Basic demographic characteristics, prodromes, signs and symptoms, exam results, interventions, complications and outcomes were registered in a standardized protocol.

Fever was defined as a temperature measured in the first $24 \mathrm{~h}$ bigger than $37,5^{\circ} \mathrm{C}$. All othervital signs were defined by the first set of available observations after presentation. Tachycardia was defined as a cardiac rhythm higher or equal 100 beats per minute, and hypotension as a systolic blood pressure below $90 \mathrm{mmHg}$. For blood test results, the first available test, in the first $48 \mathrm{~h}$ was used for reference. Laboratorial tests reference values were defined by the local laboratory normal values. The abscess size was defined as the largest found diameter. In case of multiple abscesses, was considered the largest abscess diameter. The etiology was a presumptive diagnosis, based on previous treatment history, in the first approach and thorough examination by the team.

The patients with pyogenic abscess suspicion were submitted to large spectrum antibiotics therapy. As protocol instituted by the Hospital Infection Control Commission based on the local bacterial flora, quinolone (ciprofloxacin), associated with a nitroimidazole (metronidazole) were used. The antibiotics were kept in use for 4-6 weeks.

The intervention defined in this study was the percutaneous drainage guided by ultrasound, with maintenance of drainage in situ, applied in a surgical environment, with sedation and local anesthesia. It was used a Pigtail drain with free drainage.

\section{Statistical analysis}

Was realized using Epi Info 7. The categorical variables in each group were compared with the chi-square (if $20 \%$ or more of the expected frequencies were below 5), as appropriated. The continuous variables were compared using the independent t-student sample test, $p=<0.05$ was considered statistically significant.

\section{RESULTS}

There was men predominance (70\%) with an average age of 50 years old, with peak incidence around 54 years. Half the patients had positive medical history for liver disease. Alcoholism and biliary disease were the most frequent conditions associated (40\%). Other diseases were Crohn's and dysentery (Figure 1).

Symptoms duration in average was 10.1 days with peak of 11.5. The patients were hospitalized during 26.2 days in average. Most common symptoms found in admission were abdominal pain $90 \%(9 / 10)$, jaundice $70 \%(7 / 10)$, fever, inappetence and weight loss with $40 \%$ (Table 1 ).

Clinical analysis results in admission are shown in Table 2 with inflammatory alterations (leucocytes and C-reactive protein); $40 \%$ had serum levels of urea and creatinine elevated; almost $90 \%$ had alterations in hepatic enzymes and hyperbilirubinemia; $90 \%$ had altered canalicular enzymes and $75 \%$ increased INR.

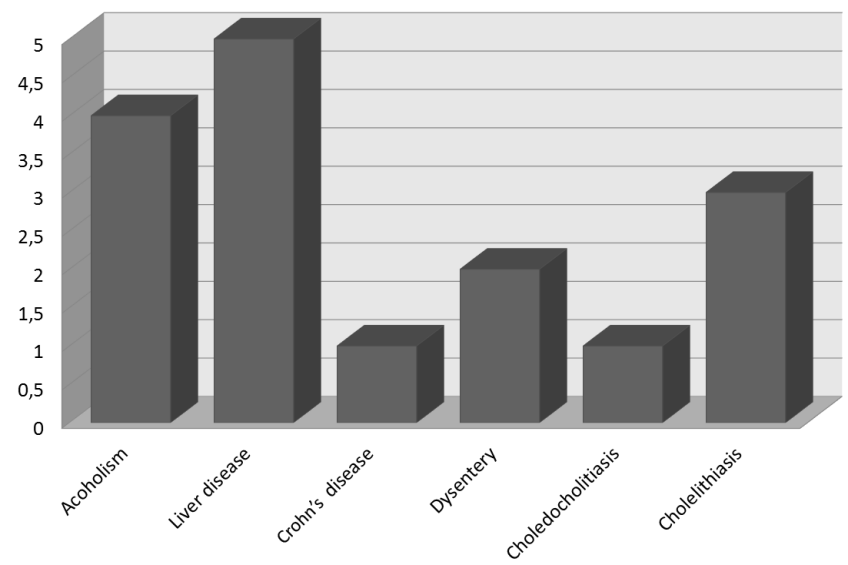

FIGURE 1 - More frequent associated conditions

TABLE 1 - Signs and symptoms

\begin{tabular}{|l|l|}
\hline & $\mathrm{n}(\%)$ \\
\hline Abdominal pain & $9(90)$ \\
\hline Jaundice & $7(70)$ \\
\hline Fever & $4(40)$ \\
\hline Weight loss & $4(40)$ \\
\hline Inappetence & $4(40)$ \\
\hline Dyspnea & $1(10)$ \\
\hline Hypotension & $1(10)$ \\
\hline Tremors & $1(10)$ \\
\hline Diarrhea & $1(10)$ \\
\hline Ascites & $2(20)$ \\
\hline Dizziness & $2(20)$ \\
\hline Vomiting & $1(10)$ \\
\hline Dysphagia & $1(10)$ \\
\hline Asthenia & $1(10)$ \\
\hline Other & $3(30)$ \\
\hline n=patients & \\
\hline
\end{tabular}

TABLE 2 - Clinical analysis results in admission

\begin{tabular}{|c|c|c|c|}
\hline & Reference & Average \pm SD & $\begin{array}{c}\text { \% of patients } \\
\text { outside } \\
\text { reference value }\end{array}$ \\
\hline Leucocytes & $05-10 \mathrm{mil} / \mathrm{mm}^{3}$ & $25,62 \pm 16,47$ & 89 \\
\hline Hemoglobin & $12-15 \mathrm{~g} / \mathrm{dl}$ & $10,99 \pm 1,91$ & 0 \\
\hline Platelets & $130-450 \mathrm{mil} / \mathrm{mm}^{3}$ & $294,40 \pm 134,01$ & 20 \\
\hline PCR & $<5 \mathrm{mg} / \mathrm{l}$ & $236,10 \pm 71,88$ & 100 \\
\hline Urea & $18-45 \mathrm{mg} / \mathrm{dl}$ & $70,50 \pm 63,79$ & 44,44 \\
\hline Creatinine & $0,7-1,3 \mathrm{mg} / \mathrm{dl}$ & $2,67 \pm 3,61$ & 33,33 \\
\hline Albumin & $3,4-4,8 \mathrm{~g} / \mathrm{dl}$ & $2,66 \pm 0,69$ & 80 \\
\hline AST & $5-34 \mathrm{U} / \mathrm{l}$ & $204,50 \pm 192,75$ & 88,89 \\
\hline ALT & $<56 \mathrm{U} / \mathrm{l}$ & $180,30 \pm 149,90$ & 88,89 \\
\hline AP & $<120 \mathrm{U} / \mathrm{l}$ & $249,11 \pm 101,46$ & 100 \\
\hline GGT & $12-64 \mathrm{U} / \mathrm{l}$ & $394,44 \pm 291,89$ & 100 \\
\hline Bilirubin & $<1,3 \mathrm{mg} / \mathrm{dl}$ & $7,5 \pm 12,09$ & 75 \\
\hline INR & $0,8-1,2$ & $1,46 \pm 0,29$ & 75 \\
\hline
\end{tabular}

$\mathrm{PCR}=\mathrm{C}$-reactive protein; $\mathrm{AST}=$ aspartate transaminase; $\mathrm{ALT}=$ aspartate aminotransferase $\mathrm{AP}=$ alkaline phosphatase; $\mathrm{GGT}=$ gama glutamic transpeptidase; INR=international normalized relation.

All patients were submitted to ultrasound and tomography and $50 \%$ had multiple abscesses with average diameter of 12.54 $\mathrm{cm}$ (4-18). Right hepatic lobe was compromised in $90 \%$ of the cases and segments VI, VII e VIII in 75\% (Table 3). 
TABLE 3 - Univariate analysis of factors that can lead to death

\begin{tabular}{|c|c|c|c|}
\hline $\begin{array}{c}\text { Demographic } \\
\text { characteristics and } \\
\text { history }\end{array}$ & Death & Discharge & $\mathrm{p}$-value \\
\hline Age & $52.18(17-78)$ & $47.3(37-63)$ & 0.6690 \\
\hline Gender (M-F) & $(0-2)$ & $(6-1)$ & 0.0833 \\
\hline Prodrome (days) & $8(0.5-15)$ & $7.6(2-14)$ & 0.9215 \\
\hline Days in hospital & $34(21-48)$ & $23(3-34)$ & 0.2680 \\
\hline \multicolumn{4}{|l|}{ Clinical signs } \\
\hline Fever & 1 & 3 & 0.6666 \\
\hline Abdominal pain & 2 & 7 & 0.8000 \\
\hline Jaundice & 0 & 7 & 0.0666 \\
\hline \multicolumn{4}{|l|}{ Laboratory } \\
\hline Leucocytes & $24.9(4.5-67.2)$ & $17.4(8.8-26.4)$ & 0.5156 \\
\hline Hemoglobin & $11.1(8.5-13.3)$ & $9.1(7.1-12.2)$ & 0.1048 \\
\hline Platelets & $330(22-555)$ & $343.3121-468$ & 0.8896 \\
\hline PCR & $223.15(96.3-350)$ & $228.48(158-96.3)$ & 0.5065 \\
\hline Urea & $67.4(29-245)$ & $52.3(42-63)$ & 0.6875 \\
\hline Creatinine & $2.44(0.6-12.5)$ & $1.1(0.8-1.6)$ & 0.5513 \\
\hline Albumin & $2(1.6-2.7)$ & $2.8(2.2-3.6)$ & 0.0402 \\
\hline AST & $146.1(14-433)$ & $221(5-633)$ & 0.5604 \\
\hline ALT & $151.7(28-509)$ & $124(6-342)$ & 0.7868 \\
\hline Alkaline Phosphatase & $263.2(136-404)$ & $236(223-249)$ & 0.7362 \\
\hline GGT & $394.4(137-1121)$ & $113.5(90-137)$ & 0.2243 \\
\hline Bilirubin & $7.7(0.9-40.1)$ & $1.4(0.1-2.7)$ & 0.4908 \\
\hline INR & $1.38(1.05-1.9)$ & $1.43(1.38-1.48)$ & 0.8037 \\
\hline \multicolumn{4}{|l|}{ Microbiology } \\
\hline Positive culture (\%) & $7(63.64)$ & $1(33.33)$ & 0.3846 \\
\hline \multicolumn{4}{|l|}{ Image } \\
\hline Diameter (median) & $14(9.6-18.2)$ & $5(4-16)$ & 0.0839 \\
\hline Diameter > 5cm (\%) & $1(12.5)$ & $7(87.5)$ & 0.2222 \\
\hline Right hepatic lobe (\%) & $2(22.22)$ & 7 (77.78) & 0.8 \\
\hline Left hepatic lobe (\%) & $0(0)$ & $1(12.5)$ & \\
\hline \multicolumn{4}{|l|}{ Presumed cause } \\
\hline Cryptogenic & 0 & 2 & \\
\hline Biliary & 0 & 2 & \\
\hline Portal & 2 & 4 & \\
\hline
\end{tabular}

$\mathrm{CRP}=\mathrm{C}$-reactive protein; $\mathrm{AST}=$ aspartate transaminase; $\mathrm{ALT}=$ aspartate aminotransferase GGT=gama glutamic transpeptidase; INR=international normalized relation

The culture was positive in $70 \%$ of the patients and the most prevailed microorganism isolated was Escherichia coli in $50 \%$, followed by multiresistent beta-lactamase extendedspectrum (ESBL MR) in 25\%. Figure 2 shows the etiology.

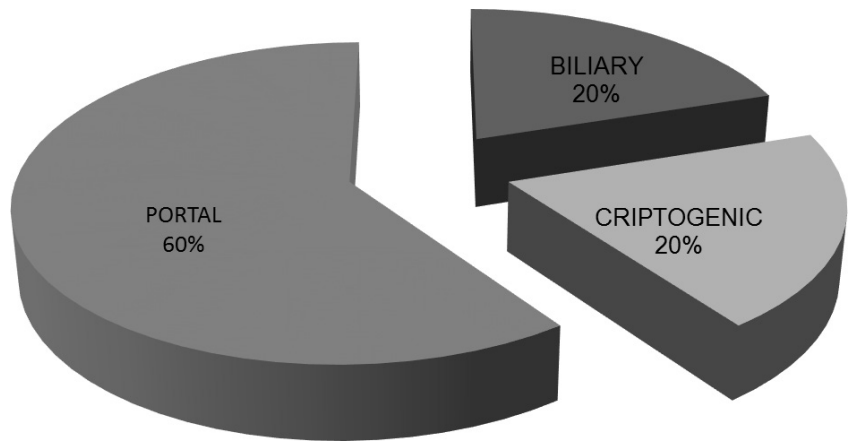

FIGURE 2 - Pyogenic hepatic abscess etiology

Every patient received intravenous antibiotic therapy and ultrasound guided drainage; one (10\%) received a second drainage; one needed an open surgical approach; two patients died (20\%).
Men predominated. Data found in this study is in consonance with others ${ }^{6,10,14}$. On the present series hepatic abscess was more common in adults with 50 years old, 10 years earlier in relation to literature. The age difference between deaths and good outcome had no statistic significance $(p=0.6690)$. Meddings et $a l .{ }^{10}$ in a population based study found patients between 18-84 years old, with $42.9 \%$ prevalence between 65-85. Pang et al. ${ }^{14}$ found an average of 64 years and Küster -Filho et al. ${ }^{8}$ average of 30.8 years. In more recent studies, it can be observed a higher preponderance on the elderly.

The clinical presentation show unspecific signals and symptoms. Abdominal pain, jaundice, fever, inappetence and weight loss were the most common. These data are also the ones found in the literature ${ }^{9,14}$. This strengthens the fact that hepatic abscess diagnosis is made with high clinical suspicion, given the low prevalence and unspecific symptoms. It can explain the average of 8.2 days for diagnosis, what suggest subacute evolution ${ }^{14}$

Laboratorial analysis showed leukocytosis $(89 \%, p=0.5156)$, with an expressive increase in CRP $(p=0.5065)$, average of $236.10 \mathrm{mg} / \mathrm{l}$, although both without statistical significance associated with hypoalbuminemia $(p=0.0402)$ in $80 \%$ of patients, suggesting inflammatory response. Unspecific data was also found in other studies ${ }^{8,14}$. For Küster-Filho et al. ${ }^{8}$ liver enzymes elevation (AST, ALT), canalicular ones (GGT, $A P$ ), and bilirubin elevation are found in higher frequency. These data were not comparable with this series, with these alterations being found respectively in $88.9 \%$; $88.9 \% ; 100 \%$; $100 \%$; and $75 \%$ without statistical significance.

The main cause found in this study was portal, secondary to abdominal cavity contamination. Such results differ from the literature showing preponderance of biliary causes in $44 \%$ of patients ${ }^{8}$ or, as Pang et al. ${ }^{14}$, cryptogenic causes in $34 \%{ }^{14}$.

The most common microorganism isolated was Escherichia coli, similar to Küster-Filho et al. ${ }^{8}$ and Meddings ${ }^{10}$ papers, despite of etiology. In Brazilian study ${ }^{8}$ biliary causes were more common, but in Americans portal causes ${ }^{10}$ prevailed. Asian series showed a great proportion of patients with Klebsiella associated with cryptogenic etiology ${ }^{4}$, mainly in diabetic group ${ }^{9}$.

The abdominal ultrasound had $40 \%$ sensibility to diagnose abscesses while abdominal CT scan had $90 \%$. Abscesses were located, in majority, in the right hepatic lobe as single abscesses measuring $12.54 \mathrm{~cm}$. Küster-Filho et al. ${ }^{8}$ found preponderance of multiple abscesses, in the right lobe, measuring $7.33 \mathrm{~cm}$ in average.

Antibiotics associated with puncture and drainage have found better results in reference of morbidity and mortality, compared to antibiotic therapy and puncture or open surgery ${ }^{5,8,14}$. Yu-Long et al. ${ }^{16}$ in a systematic revision with meta-analysis of five RCT comparing puncture and drainage concluded that drainage was superior in success rate $(p=0.04)$, clinical improvement $(p=0.0001)$ and reduction in days to reduce the abscess size in $50 \%(p<0.00001)$.

This study showed mortality of $20 \%$, high when compared to Pang et al. ${ }^{14}(6.3 \%)$ and a historic Australian series (8\%) ${ }^{1}$, but explained by the enrollment of bad cases, one patient with Chron's disease presented generalized peritonitis and multiples enterocutaneous fistulae and another had bronchial aspiration. In the USA this rate is around $5.6 \%$, decreasing from prior $6-19 \%{ }^{10}$.

Hospital stay showed association with death, with an average of 48 days in the death group $(p=0.0153)$, while in good outcome it was in average 21.63 , not surpassing 34 days. 


\section{CONCLUSION}

The pyogenic liver abscess has subacute evolution which makes the diagnosis more difficult. Image exams have high sensitivity, particularly computed tomography. Percutaneous drainage associated with antibiotic therapy is safe and effective therapeutic resource.

\section{REFERENCES}

1. Barakate MS, Stephen MS, Waugh RC, Gallagher PJ, SolomonMJ, Storey DW, Sheldon DM. Pyogenic liver abscess: a review of 10 years' experience in management. Aust N Z J Surg. 1999; 69: 205-209.

2. Cai YL, Xiong XZ, Lu J, Cheng Y, Yang C, Lin YX, Zhang J, Cheng NS. Percutaneousneedleaspirationversuscatheterdrainageinthemanagement of liver abscess: a systematic review and meta-analysis. HPB. 2015; 17(3):195-201.

3. Cerwenka $H$, Bacher $H$, Werkgartner $G$, El-Shabrawi $A$, Kornprat $P$, Bernhardt GA, Mischinger HJ. Treatment of patients with pyogenic liver abscess. Chemotherapy. 2005; 51:366-369.

4. Chen SC, Yen CH, Tsao SM, Huang CC, Chen CC, Lee MC, Bell WR. Comparison of pyogenic liver abscesses of biliary and cryptogenic origin. An eight-year analysis in a University Hospital. Swiss Med Wkly. 2005:135:344-351.

5. Johannsen EC, Sifri CD, Madoff LC. Pyogenic liver abscesses. Infect Dis Clin North Am. 2000;14:547-563.

6. Kao WY, Hwang CY, Chang YT, Su CW, Hou MC, Lin HC, Lee FY, Lee SD, Wu JC. Cancer risk in patients with pyogenic liver abscess: a nationwide cohort study. Aliment Pharmacol Ther 2012; 36: 467-476.
7. Kaplan GG, Gregson DB, Laupland KB. Population-based study of the EPidemiology of and the risk factors for pyogenic liver abscess. Clin Gastroenterol Hepatol. 2004;2:1032-8.

8. Küster Filho ACC, Kruger MR, Pacheco AL, Souza Filho ZA. Abscessos hepáticos piogênicos:empregodosrecursos diagnósticoseterapêuticos. Rev. Col. Bras. Cir. 1998; 25(6): 369-374.

9. Lee KT, Wong SR, Sheen PC. Pyogenic liver abscess: an audit of 10 years' experience and analysis of risk factors. Dig Surg. 2001; 18: 459-465.

10. Meddings L, Myers RP, Hubbard J, Shaheen AA, Laupland KB, Dixon E, Coffin C, Kaplan GG. A population-based study of pyogenic liver abscesses in the United States: incidence, mortality, and temporal trends. Am J Gastroenterol. 2010;105(1):117-24.

11. Mischinger $\mathrm{HJ}$, Hauser $\mathrm{H}$, Rabl H, Quehenberger F, Werkgartner G, Rubin $R$, Deu E. Pyogenic liver abscess: studies of therapy and analysis of risk factors. World J Surg. 1994;18:852-857.

12. Ochsner A, Oebakey M, Murray S. Pyogenic abscess of the liver, II: an analysis of forty-seven cases with review of the literature. Am J Surg. 1938;40:292-319.

13. Orsetti AG, Markiewicz P, Epstein MG, Conceição OJG, D'Ippolito G, Ribeiro MAF. Liver abscesses by chromobacterium violaceum: a case report of a rare disease. OA Case Reports. 2013;2(2):19.

14. Pang TC, Fung T, Samra J, Hugh TJ, Smith RC. Pyogenic liver abscess: An auditof10years' experience. WorldJ Gastroenterol.2011;17(12):1622-1630.

15. Wong WM, Wong BC, Hui CK, Ng M, Lai KC, Tso WK, Lam SK, Lai CL. Pyogenic liver abscess: retrospective analysis of 80 cases over a 10-year period. J Gastroenterol Hepatol. 2002;17:1001-1007.

16. Yu SC, HoSS, Lau WY, Yeung DT, Yuen EH, Lee PS, Metreweli C. Treatment of pyogenic liver abscess: prospective randomized comparison of catheter drainage and needleaspiration. Hepatology.2004; 39:932-938. 